\title{
REVIEW OF THE INTERNATIONAL SCIENTIFIC CONFERENCE "SERBIA-UNITED STATES RELATIONS" AND THE MONOGRAPH "SERBIA-UNITED STATES RELATIONS"
}

\author{
Darko Obradović
}

Faculty of Security Studies, University of Belgrade, Serbia

\section{THE INTERNATIONAL SCIENTIFIC CONFERENCE "SERBIA-United STATES Relations"

On 11 September 2019, the Institute for National and International Security organized and hosted the International Scientific Conference "Serbia-United States Relations", which was held on the premises of the National Assembly of the Republic of Serbia. The conference was realized in partnership with the National Assembly of the Republic of Serbia and the Archives of Vojvodina. The domestic and foreign expert public expressed great interest in attending the first (and rather unique) conference of this type, which was reflected in the total number of over 250 participants (Serbian and American professors and experts, Serbian ministry representatives and MPs, and the diplomatic corps). ${ }^{1}$ Given the fact that the conference focused on significant and often complex Serbia-US relations, the organizer strongly believes that the conference has contributed to strengthening the relations between the two countries and promoted the understanding of the Serbian scientific community and state actors on major issues.

The conference was opened by the Vice President of the National Assembly of the Republic of Serbia, prof. Vladimir Marinković. He emphasized that relations between Serbia and the United States have been advancing in the past few years and are ultimately moving in the direction of establishing closer cooperation and strategic partnership between the two countries. The United States and its citizens generate a large body of ideas, initiatives, business activities and innovations that benefit the entire planet. The US economy is an example of a long-term process of continuous growth and progress that promotes the spirit of entrepreneurship, culture and work ethics, and creates new opportunities for citizens to pursue

\footnotetext{
Received November $28^{\text {th }}, 2019 /$ Accepted December $4^{\text {th }}, 2019$

Corresponding author: Darko Obradović, BSc in Security Management, Executive Secretary at Institute for National and International Security, Faculty of Security Studies, University of Belgrade;

e-mail: obradovic@intelligence-security.rs

${ }^{1}$ See: National Assembly of the Republic of Serbia: National Assembly Hosts International Scientific Conference "Serbian-American Relations", 11 September 2019; available at: http://www.parlament.gov.rs/ National_Assembly_Hosts_International_Scientific_Conference_\%E2\%80\%9CSerbian-

American_Relations\%E2\%80\%9D_.37236.537.html (accessed 12.12.2019)
} 
prosperity, development and progress. Serbia is in a very complex geopolitical position but it is committed to modernizing, advancing and creating a quality environment for prosperous life of its citizens. US companies in Serbia employ 17,000 Serbian citizens; the US strongly supports EU integration of Serbia, most importantly by taking into consideration Serbia's legitimate interests. Thus, it is important to take every opportunity to strengthen cooperation with the US, particularly in terms of developing new partnerships, business and investment opportunities, cooperation with the Serbian diaspora, US Congress and the State Department, universities, and other institutions. Prof. Marinković pointed out that, as responsible people, we will continue working in the interest of developing our own state and promoting cooperation with the US, hoping that a possible strategic partnership can generate closer links between the two countries, which we had at the time when they were allies.

The conference participants were then addressed by the first Vice Prime Minister and the Minister of Foreign Affairs of the Republic of Serbia, Ivica Dačić, who referred to the long-standing history of Serbia-US relations. In terms of history, our two countries and peoples are connected by an alliance in the two world wars as well as by cooperation during the Cold War. Minister Dačić stressed the importance of recalling the positive examples from the long history of Serbia-US relations. Throughout history, Washington has shown understanding for the fight for the liberation of a small and remote Balkan nation. Minister Dačić highlighted the event of Raising of the Serbian flag at the White House on 28 July 1918, in honor of brave Serbian people who, as state by President Wilson, embarked on a battle against a significantly superior enemy. Minister Dačić referred to the alliance and partnership during the Second World War and the Cold War, as well as the challenges and difficulties over the last thirty years. In addition to the rich history of bilateral relations and alliances in the two world wars, he underscored a common strategic commitment to ensuring security and economic stability of the region as ultimate values that should shape Serbia-US relations. He noted that the current relations between the two countries are marked by positive dynamics and Serbia's goal to advance our bilateral relations, which is constantly reflected in the demonstrated interest to maintain regular political dialogue at the highest level with US officials. Serbia wants to reaffirm itself as an active, proven and reliable partner, and a pillar of regional stability. In the end, Minister Dačić emphasized the need to overcome the negative views and biases of the recent past, and to take joint action in building cooperation between the two states and their peoples based on the common values and interests.

The current US Ambassador of the US in Serbia, Mr. Kyle Scott, referred to the 140 years of diplomatic relations, strong historic ties and strategic alliance between the two countries, as well as to ongoing US efforts to advance the bilateral relations, provide financial support and assistance, and contribute to promoting Serbia's stability and further development.

The conference participants were greeted by prof. Darko Trifunović, Director of the Institute for National and International Security, and MP Dragan Šormaz in front of the Parliamentary US-friendship group (PFG), and subsequently addressed by: Mrs. Biljana Popović Ivković, the State Secretary at the Ministry of the Interior; Mr. Aleksandar Živković, the State Secretary at the Ministry of Defence; and Major General John Harris Jr., Ohio National Guard.

In the operative part of the conference, scholars and experts from different fields of expertise presented their papers and exchanged experiences and views on the Serbia-US relations involving different aspects of cooperation between the two countries: geopolitical and security cooperation, educational and scientific cooperation, international cooperation in criminal matters, the US contribution to the development of Serbian public services, etc. 


\section{OVERVIEW OF THE MONOGRAPH “SERBIA-UNITED STATES RELATIONS”}

One of the significant results of this international scientific conference is the publication of the monograph, titled "Serbia-United States Relations", which clearly demonstrates the joint efforts of scientists from Serbia and the United States to explore, reconsider and promote Serbia-United States relations. The Scientific Committee of the monograph brought together scientists from Serbia, Israel, China, Greece, Romania, Slovakia, Slovenia and Germany, demonstrating high international scientific interest in Serbia-US relations.

In their scientific articles, the authors covered a wide range of topics and aspects of Serbia-US relations, including the new strategic framework for for US-Serbia relations, geopolitical and security aspects, historical perspective, the US impact on the development of Serbian public institutions, criminal law cooperation and related agreements, economic cooperation, the prospects for the 21 st century, etc. An issue of particular interest is the authors' qualitative approach to the topics presented in this monograph.

Gregory R. Copley (PhD), an expert from the International Strategic Study Association, elaborates on a new strategic framework for US-Serbia relations and points out that this period in history provides a unique opportunity for the advancement of these relations. This new framework offers an opportunity for Serbia to fill in the existing vacuum, thread its way as a proven historical ally, and impose itself as a loyal and reliable partner in the Balkans. The author argues that Serbia has a chance to incline to and incorporate itself into the new strategic approach of the USA in the Balkans only by redesigning and reorganizing its existing strategic cooperation framework. The mutual relations between the two countries slowly began to decline during the socialist Yugoslavia. At the same time, other countries (such as Russia, the PR China and Turkey) have been trying to exert its own influence in the region. In the current circumstances, the United States should take the opportunity to do the same, particularly in terms of supporting a resolution of conflict between Serbs and Albanians regarding Kosovo and Metohija.

Darko Trifunović $(\mathrm{PhD})$ and Zoran Dragišić $(\mathrm{PhD})$, professors of the Faculty of Security, University of Belgrade, discuss the geopolitical and security aspects of Serbia-US relations. They provide evidence of the long-standing alliance between Serbia and the USA, which was disturbed during the rule of the pro-Bolshevik dictator Slobodan Milošević. To support this thesis, the authors point out to the constructive role of President Wilson, who had a great respect for the heroic battle of the Serbian people in World War I and played a significant role in defining the borders of the Kingdom of Serbs, Croats and Slovenes after the Great War. The period of history behind us shows that Yugoslavia, as a communist and later socialist state, was a constructive ally of the West and enjoyed all possible benefits from the United States. The authors consider that the greatest success of the neo-Stalinist ideology was to turn Serbia against the West and put the Serbian people in the service of Russia's foreign policy interests. The authors conclude that Serbia and the Serbian people have been victims of ideologists' propaganda, global political influences and economic interests.

Steven Oluic $(\mathrm{PhD})$, a retired US Army colonel, discusses Serbia's geopolitical position and direction in terms of choosing its geopolitical (East or West) way forward. The US

\footnotetext{
${ }^{2}$ See: Proceedings / International Scientific Conference "Serbian-American Relations", Belgrade, 11 Sept. 2019; [eds. Nebojša Kuzmanović, Darko Trifunović].- Novi Sad : Archives of Vojvodina; Belgrade: Institute for National and International Security, 2019. ISBN 987-86-80017-61-7; abailable at: http://intelligence-security.rs/assets/img/Serbian\%20American\%20Relations.pdf (accessed 11.11.2019)
} 
global hegemony has been overcast by other global competitors. He identifies Russia's recent successes in Syria and China's "Road and Belt Initiative" project as economic, military and geopolitical challenges for the US and the Western countries. While the former Yugoslavia had long been a "shelter belt" region, Serbia is a borderland European state largely outside the Western central sphere of interest but increasingly subject to the Russian, Chinese and Turkish spheres of interest in the Balkan region. He concludes that the legacies of recent past, geopolitical challenge and potential opportunities are most likely to continue governing Serbia's way forward.

Orhan Dragaš $(\mathrm{PhD})$, an expert from the International Security Institute (ISI)-Serbia, examines the historical context of Serbia-US relations and proposes "Five Points for Building new Serbia-US Relations in the 21st Century". The Serbia-US relations have always had their ups and downs, periods of friendship and fraternity, as well as periods of broken relations and even armed conflicts. The author perceives the last 30 years' period as a low point in the history of Serbia-US relations, and strongly believes the broken relations can be repaired. To that effect, the author proposes five points of reference that may actually contribute to establishing links and fostering cooperation between Serbia and the USA. These connecting points are technology, security, culture, personal ties and relations, and historical connections, which can help redefine and improve Serbia-US relations.

Further in this monograph, the authors discuss a wide range of related issues: the impact of the US on public administration reform and establishment of public agencies in Serbia (P. Dimitrijević, D.Vučetić, J. Vučković); the economic perspective of Serbia-US relations and importance of US Government donations for the needs of the Serbian population and the Serbian Army (D. Obradović); the implementation of international treaties and bilateral agreement on the extradition of perpetrators of serious crimes, including the European Arrest Warrant agreement (M. Kostić, G. Pantić, N. Obradović); the need to reinvent Serbia-US relations by focusing on shared values and mutual interests (P. Cvetković); and a number of other subject-specific topics, such as: Serbian immigration and contribution of the Serbian Diaspora to American religion, science and US-Serbia international relations (E. Isaac); Serbian-American heroes of WW II (G. Moore), and portraits of four SerbianAmericans decorated by medals of honour for their services in the US Army, Navy and Air Force in WW II (J.Adams); US role in the annexation of Voivodina to the Kingdom of Serbia in 1918 (S. Marković); Serbia's cooperation with neighboring states in counteracting migrant crisis and extremism (J. Nomikos); the role of archives in international cooperation (N. Kuzmanović, Lj. Dožić); and the role of technology in industry-driven education (M.Božić).

On the whole, the International Scientific Conference "Serbia-United States Relations" and the related monograph represents a significant scientific contribution to the understanding and advancement of Serbia-US relations. They have certainly contributed to breaking the taboo topic in the Serbian scientific community, raising awareness of SerbiaUS relations, and addressing the issues from different perspectives in an impartial and ideologically neutral manner. 